\title{
JURNAL
}

TEKNOLOGI INFORMASI

\section{Klasterisasi kinerja karyawan menggunakan algoritma fuzzy c- means}

\author{
Martin ${ }^{1)}$, Yessica Nataliani ${ }^{2)}$ \\ Program Studi Sistem Informasi \\ Fakultas Teknologi Informasi \\ Universitas Kristen Satya Wacana Salatiga \\ Jl. O. Notohamidjojo, Salatiga 50711, Indonesia
}

Email : 682017157@student.uksw.edu, yessica.nataliani@uksw.edu

\begin{tabular}{ll}
\hline Recieved: $15-02-2021$ & $\begin{array}{c}\text { Riwayat artikel: } \\
\text { Revised:18-02-2021 }\end{array}$ Accepted:19-02-2021 \\
\hline
\end{tabular}

\begin{abstract}
Reward and punishment are needed for assessing employees' performance. Employee grouping based on their performance is one of several ways to enhance employees' performance. This research discusses about grouping employess based on their performance using Fuzzy C-Means. Result from assessment comes from the total of each criteria that contains of presence, discipline, and task duration. Three groups of employees are formed, which are good, moderate, and bad. From 13 employees, 10 of them are in the good criteria, one is in moderate criteria, and two are in the bad one. We also use different values of fuzzy exponent to get the clustering results. The values 1.5 and 2 of fuzzy exponents give the same clustering results with the result from manager. Therefore, grouping with FCM could be used to cluster employees based on their performance.
\end{abstract}

Keywords: employees’ performance, clustering, fuzzy c-means

\begin{abstract}
Abstrak
Penilaian kinerja karyawan diperlukan perusahaan untuk memberikan reward dan punishment kepada karyawan. Pengelompokan karyawan berdasarkan kinerjanya dapat dikatakan sebagai satu cara yang digunakan untuk meningkatkan performa karyawan. Penelitian ini membahas tentang pengelompokan karyawan berdasarkan kinerjanya menggunakan algoritma Fuzzy C-Means. Penilaian kinerja karyawan didapat dengan menjumlahkan nilai masing-masing kriteria penilaian, yang terdiri dari presensi, kedisiplinan, dan waktu penyelesaian pekerjaan, Penelitian ini bertujuan mendapatkan tiga kelompok karyawan, yaitu kelompok dengan kriteria baik, sedang, dan tidak baik. Dari penelitian terhadap 13 karyawan dihasilkan 10 karyawan pada kriteria baik, satu karyawan pada kriteria sedang, dan dua karyawan pada kriteria tidak baik. Selain itu, digunakan eksponen fuzzy yang berbeda untuk melihat pengaruhnya terhadap hasil pengelompokan, dan dihasilkan bahwa dengan nilai 1.5 dan 2, hasil pengelompokan dari FCM sama dengan hasil pengelompokan karyawan yang dilakukan oleh manajer. Pengelompokan dengan FCM dapat digunakan untuk mengelompokkan karyawan berdasarkan kinerjanya.
\end{abstract}

Kata kunci: kinerja karyawan, pengelompokan data, fuzzy c-means 


\section{Pendahuluan}

Perkembangan teknologi informasi saat ini telah berkembang dengan sangat cepat dalam segala aspek kehidupan. Data yang di dapat dari perkembangan teknologi informasi ini sangatlah jauh lebih baik dari pada sebelumnya. Tentu banyak perusahaan besar di Indonesia yang memanfaatkan teknologi tersebut. Namun beberapa masalah sering terjadi di dalam sebuah perusahaan, seperti dalam menjaga semangat para karyawan suatu perusahaan. Hal ini dapat dilakukan dengan cara menaikkan gaji, menaikkan THR ataupun memberikan bonus, sesuai kinerja setiap karyawan. Setiap perusahaan mempunyai kriteria sendiri untuk menilai kinerja para karyawannya. Tingkat kesulitan pekerjaan yang di alami tiap karyawan tidaklah sama. Terkadang ada karyawan yang mendapatkan nilai rendah dalam kinerjanya, bukan karena dia tidak mampu mengerjakannya melainkan pekerjaannya yang terlalu berat. Hal ini menimbulkan ketidakadilan bagi para karyawan.

Oemah Djari Kitchen yang berada di Jalan Merdeka Selatan III No. 17, Sidorejo Lor, Kecamatan Sidorejo, Kota Salatiga, Jawa Tengah 50714 merupakan sebuah restoran yang didirikan pada tanggal 3 November 2017. Oemah Djari dibentuk oleh beberapa rekan kerja sesama keluarga. Restoran ini mempunyai misi dan visi untuk menjadi restoran terbaik di Kota Salatiga dengan cara memberikan pelayanan yang berkualitas, menyajikan makanan dengan rasa yang nikmat, dan menggunakan bahan-bahan dengan kualitas yang baik. Di kalangan masyarakat Salatiga, Oemah Djari terlihat hanya berfokus di kalangan keluarga saja, namun dari pernyataan manajernya, mereka tidak hanya berfokus di kalangan keluarga saja melainkan di semua kalangan seperti mahasiswa, pegawai negeri sipil, dan lainlain. Sayangnya, mereka belum mempunyai sistem untuk mengelompokkan kinerja karyawan berdasarkan presensi, waktu penyelesaian pekerjaan, dan kedisiplinan masing-masing karyawan.

Klasterisasi merupakan pengelompokan data dimana data yang mempunyai karakteristik serupa akan dikelompokkan menjadi satu klaster dan data yang berbeda akan berada pada klaster yang lain. Ada berbagai macam metode klasterisasi, diantaranya adalah fuzzy c-means (FCM). FCM merupakan suatu proses klasterisasi (pengelompokan) data yang keberadaan suatu titik data pada suatu klaster ditentukan dengan derajat keanggotaan. FCM adalah suatu metode penganalisis klaster yang memperhitungkan tingkat nilai keanggotaan yang terdapat di dalam himpunan fuzzy sebagai dasar pembobotan suatu klaster atau kelompok. Keunggulan fuzzy klasterisasi adalah dapat menyatukan atau mengelompokan objek-objek yang tersebar berantakan. Apabila terdapat data yang penyebarannya berantakan, maka ada kemungkinan data tersebut berada pada klaster lain. Perulangan didasarkan pada peminimalan fungsi objektif yang menunjukkan jarak dari titik data yang diberikan ke pusat klaster yang terbobot oleh 
derajat keanggotaan titik data tersebut. Output FCM berupa deretan pusat klaster dan derajat keanggotaan terhadap setiap klaster [1].

Berdasarkan masalah yang ada maka dibuatlah penelitian untuk mengelompokkan karyawan sesuai dengan kinerjanya menggunakan FCM di Oemah Djari. Dengan metode FCM ini diharapkan mampu memberikan hasil untuk sebuah pusat klaster yang dapat menunjukkan nilai kinerja karyawan dan mendapatkan hasil penilaian sesuai dengan nilai yang diperoleh tiap karyawan. Ada tiga kriteria yang akan diterapkan dalam penilaian ini yaitu penilaian kedisiplinan, absensi, dan waktu penyelesaian pekerjaan. Dengan metode ini perusahaan dapat menentukan baik tidaknya kinerja seorang karyawan dan mampu memberikan nilai optimal yang diperoleh tiap karyawan dalam suatu perusahaan. Selanjutnya juga akan diteliti bagaimana pengaruh nilai eksponen fuzzy yang berbeda terhadap hasil pengelompokan. Hasil dari penelitian ini diharapkan dapat membantu menentukan gambaran kelompok karyawan dan penerapan algoritma FCM pada pengelompokan karyawan yang berada di Oemah Djari Salatiga.

\section{Kajian Pustaka}

Penelitian mengenai pengelompokan data yang bertujuan mendapatkan suatu informasi tentang kinerja karyawan tidaklah yang pertama kali diteliti, telah ada beberapa penelitian terdahulu yang membahas tentang klasterisasi tersebut.

Berdasarkan penelitian terdahulu yang berkaitan dengan klasterisasi kinerja karyawan menggunakan algoritma FCM diantaranya dilakukan oleh Wulandari dan Setiawan yang melakukan klasterisasi kinerja karyawan berdasarkan dua kriteria penilaian yaitu penilaian kontribusi utama dan penilaian umum dengan tujuan menghasilkan kelompok klaster yang tepat dan akurat untuk tiap-tiap karyawan [2].

Penelitian tentang Penerapan Algoritma K-Means Clustering yang dilakukan oleh Nasari dan Sianturi menghasilkan pusat klaster penyebaran diare yang berada di Kabupaten Langkat. Pusat klaster pertama berada pada kecamatan Batang Serangan, Brandan Barat dan Pematang Jaya dan pusat klaster kedua berada pada kecamatan Hinai, Sei Bingai, dan Sirapit [3].

Pada penelitian yang dilakukan oleh Agustina dan Prihandoko yang berjudul Perbandingan Algoritma K-Means dengan Algoritma Fuzzy C-Means untuk Clustering Tingkat Kedisiplinan Kinerja Karyawan bertujuan untuk menemukan pusat centroid setiap klaster, yang berbeda pada metode algoritma $k$ means dan FCM. Hasil penelitian ini dapat dinyatakan bahwa hasil klaster dari data presensi karyawan menggunakan metode k-means dan FCM tidaklah sama atau berbeda [4].

Dari ketiga penelitian di atas terdapat keselarasan dengan penelitian ini sehingga akan dilakukan klasterisasi menggunakan algoritma FCM untuk proses 
penilaian kinerja karyawan berdasarkan kinerjanya di Oemah Djari Kitchen Salatiga.

Klasterisasi dengan fuzzy merupakan suatu teknik yang digunakan untuk menentukan klaster optimal pada suatu ruang vektor berdasarkan bentuk normal Euclidean untuk jarak tiap-tiap vektor. Klasterisasi dengan fuzzy berguna pada pemodelan fuzzy terutama untuk mengidentifikasi aturan-aturan fuzzy. Kelebihan FCM salah satunya adalah menempatkan pusat klaster yang lebih akurat dibandingkan metode klaster lain [5]. Ada dua metode yang terdapat di dalam fuzzy clustering, yaitu Fuzzy C-Means (FCM), adalah algoritma klasterisasi yang tidak terawasi dimana banyaknya klaster yang akan dibentuk harus ditentukan terlebih dahulu, dan Fuzzy Subtractive Clustering (FSC), adalah algoritma pengelompokan yang tidak terawasi dimana jumlah klaster tidak diketahui sebelumnya. FSC didasari dengan ukuran kerapatan tiap-tiap titik data yang berada di dalam suatu ruang (variabel) [6]. Konsep awal dari klasterisasi subtraktif adalah menentukan daerah dalam suatu variabel yang memiliki potensi besar terhadap titik klaster yang ada di sekelilingnya. Sebuah titik yang memiliki tetangga dengan jumlah terbanyak akan dijadikan sebagai pusat klaster. Titik yang telah dipilih sebagai pusat klaster akan mendapatkan pengurangan potensi. FCM akan memilih mana titik yang mempunyai jumlah tetangga paling banyak untuk dijadikan sebagai pusat klaster lainnya. Hal ini harus dilakukan pengulangan berkali-kali sehingga semua titik teruji [7].

FCM merupakan suatu teknik pengelompokan data dimana setiap titik data pada suatu titik klaster ditentukan dengan nilai keanggotaan [8]. Teknik ini diperkenalkan pertama kalinya oleh Jim Bezdek pada tahun 1981. Langkah awal pada FCM adalah mencari pusat klaster, yang akan menempati lokasi yang seharusnya untuk tiap klaster. Pada kondisi awalnya, pusat klaster ini berada ditempat yang tidak akurat, sehingga diperlukan perbaikan secara berulang untuk mendapatkan posisi pusat klaster yang akurat. Setiap data memiliki derajat keanggotaan pada tiap klaster pada interval nilai $[0,1]$. Untuk memdapatkan derajat keanggotaan yang tepat maka perlu dilakukan perbaikan secara berulang juga untuk nilai keanggotaan, sehingga data menempati klaster yang tepat. Algoritma FCM digambarkan pada Gambar 1 dan dapat dijelaskan sebagai berikut:

1. Input data yang akan dikelompokkan $X$, berupa matriks berukuran $n \times m(n=$ jumlah data, $m=$ atribut setiap data), dimana $X_{i j}=$ data ke- $i(i=1,2, \ldots, n)$ dengan atribut ke- $j(j=1,2, \ldots, m)$.

2. Tentukan:

- Jumlah klaster $=c$;

- Eksponen fuzzy $=w$; 
- $\quad$ Error terkecil yang diharapkan $=\zeta$;

- Fungsi obyektif awal: $P_{0}=0$;

- Iterasi awal: $t=1$

- Bangkitkan partisi awal $\eta_{i k} ; i=1,2, \ldots n ; k=1,2, \ldots, c$, sebagai derajat keanggotaan untuk data ke- $i$ pada klaster ke- $k$.

Pada awalnya matriks partisi $\eta$ belum akurat, begitu juga dengan pusat klasternya, sehingga kecenderungan data untuk berada pada suatu klaster juga belum akurat.

3. Hitung pusat klaster ke- $k, V_{k j}$, dimana $k=1,2, \ldots, c ; j=1,2, \ldots, m$, dengan

$$
V_{k j}=\frac{\sum_{i=1}^{n}\left(\left(\eta_{i k}\right)^{w} x_{i j}\right)}{\sum_{i=1}^{n}\left(\eta_{i k}\right)^{w}}
$$

4. Hitung fungsi obyektif pada iterasi ke- $t, P_{t}$, dengan

$$
P_{t}=\sum_{i=1}^{n} \sum_{k=1}^{c} \sum_{j=1}^{m}\left(\eta_{i k}\right)^{w}\left(X_{i j}-V_{k j}\right)^{2}
$$

Fungsi obyektif digunakan sebagai salah satu syarat perulangan untuk mendapatkan pusat klaster yang tepat, sehingga pada langkah terakhir diperoleh kecenderungan data berada pada suatu klaster.

5. Perbarui matriks partisi, $\eta_{i k}$, dimana $i=1,2, \ldots n ; k=1,2, \ldots, c$, dengan

$$
\eta_{i k}=\frac{\left(\sum_{j=1}^{m}\left(X_{i j}-V_{k j}\right)^{2}\right)^{\frac{-1}{w-1}}}{\sum_{d=1}^{c}\left(\sum_{j=1}^{m}\left(X_{i j}-V_{d j}\right)^{2}\right)^{\frac{-1}{w-1}}}
$$

6. Cek kondisi berhenti: Jika $\left(\left|P_{t}-P_{t-1}\right|<\zeta\right)$, maka berhenti; jika tidak, maka $t=t+1$ dan ulangi langkah ke-3 [2] 


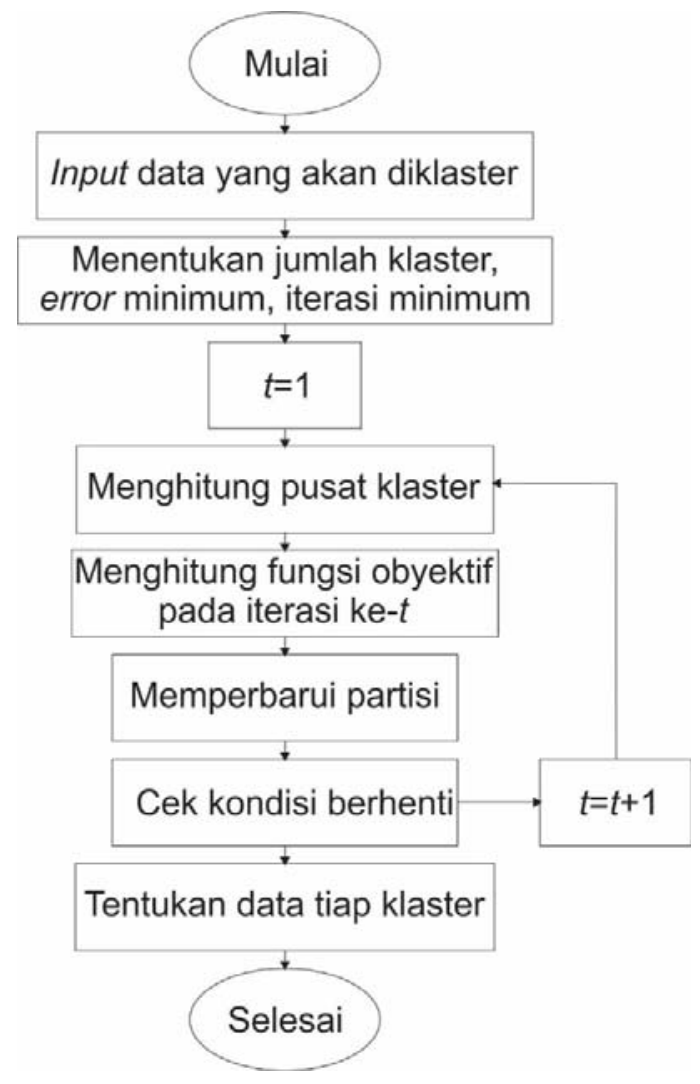

Gambar 1. Flowchart algoritma FCM

\section{Metode Penelitian}

Penelitian ini membahas pengelompokan karyawan berdasarkan penilaian kinerja yang dilakukan terhadap karyawan di Oemah Djari Kitchen, di Jalan Merdeka Selatan III No. 17, Sidorejo Lor, Kecamatan Sidorejo, Kota Salatiga, Jawa Tengah 50714. Apabila penilaian tetap menggunakan penilaian standar akan mengakibatkan hasil penilaian yang tidak akurat karena nilai kinerja karyawan yang kecil bukanlah karena karyawan tersebut tidak memiliki keahlian untuk menjalankan pekerjaannya dengan baik tetapi karena pekerjaannya yang terlalu berat. Oleh karena itu, algoritma FCM diterapkan untuk mengelompokkan karyawan berdasarkan kinerjanya. Dalam penelitian ini kinerja karyawan dinilai dari tiga kriteria, yaitu:

1. Presensi, dimana presensi merupakan poin yang penting untuk menilai kinerja karyawan. Dari presensi para atasan atau manajer bisa menilai atau mengukur gaji yang harus diberikan untuk para pegawai dengan tepat dan tidak ada salah paham antara pegawai yang presensinya bagus dengan yang presensinya kurang bagus.

2. Kedisiplinan, dimana kedisiplinan adalah salah satu nilai yang sangat penting bagi para atasan atau manajer untuk menilai para karyawannya. Kedisiplinan di 
sini mencakup tentang kedisiplinan para karyawan harus sangat ketat dinilai oleh atasan, karena para karyawan yang tidak memiliki kedisplinan yang bagus dalam melaksanakan pekerjaannya akan membuat para pelanggan merasa tidak menikmati makanan atau suasana yang ada di restoran tersebut.

3. Waktu penyelesaian pekerjaan, dimana waktu penyelesaian pekerjaan ini adalah kecepatan atau ketepatan seorang karyawan dalam melakukan tugasnya. Sebagai contoh misalnya, ketika ada tamu yang datang, maka karyawan yang bertugas sebagai pelayan harus selalu siap untuk menyambut dan memberikan buku menu, bukan sebaliknya, pelanggan yang memanggil pelayan terlebih dahulu.

Penelitian diawali dengan pengumpulan data, yang meliputi wawancara dengan manajer Oemah Djari, kemudian dilanjutkan dengan melakukan studi literatur tentang algoritma FCM untuk mengolah data tersebut. Dengan algoritma FCM, dilakukan pengelompokan untuk melakukan penilaian kinerja karyawan berdasarkan presensi, waktu penyelesaian pekerjaan, dan kedisiplinan, sehingga dihasilkan kelompok karyawan yang sesuai dengan kinerjanya. Selanjutnya, dilakukan perbandingan hasil pengelompokan kinerja karyawan menggunakan FCM dengan hasil pengelompokan yang dilakukan oleh manajer.

Analisis data merupakan proses pencarian data secara sistematis yang telah didapatkan dari hasil wawancara, catatan lapangan, dan lain-lain, dengan cara mengelompokkan masing-masing data tersebut ke dalam kategorinya dan memilih mana yang akan dipahami atau dinilai. Penilaian kinerja merupakan suatu proses penilaian tingkat kinerja karyawan yang menunjukkan seberapa baik atau buruk seseorang karyawan dalam melakukan pekerjaannya. Apabila dilakukan perbandingan dengan seperangkat standar lalu menyampaikan informasi tersebut kepada karyawan. Penilaian kinerja karyawan dapat disebut sebagai pemeringkatan karyawan, tinjauan kerja, evaluasi kinerja dan penilaian hasil [2].

\section{Hasil dan Pembahasan}

Data yang diambil terdiri dari 13 karyawan dengan tiga kriteria yang menjadi penilaian kinerja karyawan. Masing-masing kriteria diwakili oleh beberapa pertanyaan, empat pertanyaan untuk kriteria presensi, empat pertanyaan untuk kriteria kedisiplinan, dan lima pertanyaan untuk kriteria waktu penyelesaian pekerjaan. Tabel 1 merupakan hasil penilaian masing-masing kriteria yang didapatkan dengan menjumlahkan skor tiap pertanyaan pada masing-masing kriteria. 
Tabel 1 Data karyawan berdasarkan kriteria

\begin{tabular}{lccc}
\hline \multicolumn{1}{c}{ Karyawan } & Presensi & Kedisplinan & $\begin{array}{c}\text { Waktu Penyelesaian } \\
\text { Pekerjaan }\end{array}$ \\
\hline ARDIAN & 11 & 11 & 13 \\
RISKI & 11 & 11 & 13 \\
RAHMA & 11 & 11 & 13 \\
ANGGRAENI & 6 & 7 & 8 \\
AGUS & 11 & 11 & 13 \\
NOVAN & 11 & 11 & 13 \\
NENSI & 11 & 11 & 13 \\
IRUL & 11 & 11 & 13 \\
EKO NUR IMAN & 9 & 8 & 11 \\
RIVAEL & 12 & 11 & 14 \\
DIKA & 12 & 10 & 13 \\
ANDREAS & 7 & 7 & 8 \\
SAINO & 11 & 11 & 13 \\
\hline
\end{tabular}

Selanjutnya penilaian karyawan berdasarkan tiga kriteria dari Tabel 1 diolah menggunakan algoritma FCM. $X$ merupakan data angka hasil penilaian masingmasing kriteria yang terlihat pada Tabel 1, dengan jumlah data, $n=13$ dan jumlah atribut, $m=3$. Karyawan dikelompokkan menjadi tiga klaster $(c=3)$ dengan eksponen fuzzy $w=2$. Matriks partisi keanggotaan akhir yang didapat seperti terlihat pada Tabel 2, sedangkan pusat klaster akhirnya dapat dilihat pada Tabel 3.

Tabel 2 Matriks partisi keanggotaan

\begin{tabular}{lccc}
\hline \multicolumn{1}{c}{ Karyawan } & Klaster $\mathbf{1}$ & Klaster 2 & Klaster 3 \\
\hline ARDIAN & 0.0007 & 0.0027 & 0.9966 \\
RISKI & 0.0007 & 0.0027 & 0.9966 \\
RAHMA & 0.0007 & 0.0027 & 0.9966 \\
ANGGRAENI & 0.9837 & 0.0127 & 0.0036 \\
AGUS & 0.0007 & 0.0027 & 0.9966 \\
NOVAN & 0.0007 & 0.0027 & 0.9966 \\
NENSI & 0.0007 & 0.0027 & 0.9966 \\
IRUL & 0.0007 & 0.0027 & 0.9966 \\
EKO NUR IMAN & 0.0001 & 0.9998 & 0.0001 \\
SAINO & 0.0007 & 0.0027 & 0.9966 \\
RIVAEL & 0.0172 & 0.0531 & 0.9297 \\
DIKA & 0.0214 & 0.0823 & 0.8963 \\
\hline
\end{tabular}




\begin{tabular}{cccc}
\hline Karyawan & Klaster $\mathbf{1}$ & Klaster $\mathbf{2}$ & Klaster 3 \\
\hline ANDREAS & 0.9787 & 0.0172 & 0.0042 \\
\hline
\end{tabular}

Tabel 3 Pusat klaster

\begin{tabular}{rrrr}
\hline Pusat 1 & 6.4996 & 7.0013 & 8.0021 \\
Pusat 2 & 9.0276 & 8.0215 & 11.0210 \\
Pusat 3 & 11.1730 & 10.9160 & 13.0900 \\
\hline
\end{tabular}

Hasil pengelompokan karyawan yang didapat dengan FCM seperti yang dapat dilihat pada Tabel 4, sedangkan diagram titik (scatter plot)-nya dapat dilihat pada Gambar 2.

Tabel 4 Hasil pengelompokan karyawan dengan FCM

\begin{tabular}{cl}
\hline Kelompok & \multicolumn{1}{c}{ Karyawan } \\
\hline Kelompok 1 & ANDREAS \\
& ANGGRAENI \\
Kelompok 2 & EKO NUR IMAN \\
Kelompok 3 & AGUS \\
& ARDIAN \\
& DIKA \\
& IRUL \\
& NENSI \\
& NOVAN \\
& RAHMA \\
& RISKI \\
& RIVAEL \\
& SAINO \\
\hline
\end{tabular}




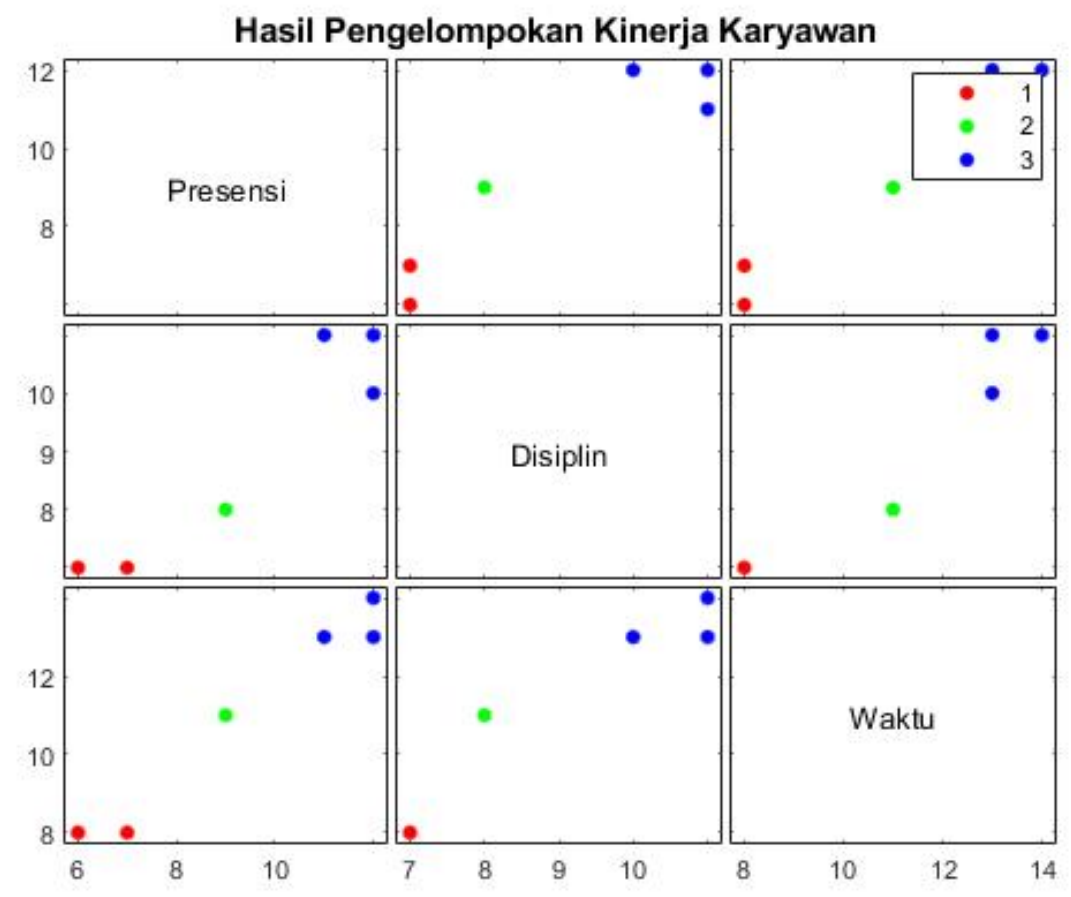

Gambar 2. Diagram titik hasil pengelompokan kinerja karyawan

Seperti yang diketahui bahwa nilai eksponen fuzzy $w$ pada FCM dapat mempengaruhi hasil pengelompokan. Oleh karena itu, dalam penelitian ini juga digunakan nilai eksponen fuzzy $w=1.1,1.2,1.5$, dan 2.5. Hasil pengelompokan dengan nilai eksponen fuzzy $w$ yang berbeda dapat dilihat pada Tabel 5.

Tabel 5 Hasil pengelompokan karyawan dengan eksponen fuzzy $w=1.1,1.2,1.5$, dan 2.5

\begin{tabular}{lllll}
\hline Kelompok & \multicolumn{1}{c}{$\begin{array}{c}\text { Karyawan } \\
(\mathbf{w}=\mathbf{1 . 1})\end{array}$} & $\begin{array}{c}\text { Karyawan } \\
(\mathbf{w}=\mathbf{1 . 2})\end{array}$ & $\begin{array}{r}\text { Karyawan } \\
(\mathbf{w}=\mathbf{1 . 5})\end{array}$ & $\begin{array}{c}\text { Karyawan } \\
(\mathbf{w}=\mathbf{2 . 5})\end{array}$ \\
\hline Kelompok 1 & ANDREAS & ANDREAS & ANDREAS & ANDREAS \\
& ANGGRAENI & ANGGRAENI & ANGGRAENI & $\begin{array}{l}\text { ANGGRAENI } \\
\text { EKO NUR IMAN } \\
\text { Kelompok 2 } 2\end{array}$ \\
& DIKA & DIKA & EKO NUR IMAN & (tidak ada) \\
Kelompok 3 3 & AGUS & AGUS & AGUS & AGUS \\
& ARDIAN & ARDIAN & ARDIAN & ARDIAN \\
& IRUL & EKO NUR IMAN & DIKA & DIKA \\
& NENSI & IRUL & IRUL & IRUL \\
& NOVAN & NENSI & NENSI & NENSI \\
& RAHMA & NOVAN & NOVAN & NOVAN \\
& RISKI & RAHMA & RAHMA & RAHMA \\
& RIVAEL & RISKI & RISKI & RISKI \\
& SAINO & SAINO & RIVAEL & RIVAEL \\
& & & SAINO & SAINO \\
\hline
\end{tabular}


Selanjutnya dengan mengurutkan pusat klaster dapat disimpulkan bahwa Kelompok 1 merupakan klaster karyawan dengan kinerja terburuk, Kelompok 2 merupakan klaster kinerja sedang, dan Kelompok 3 merupakan klaster kinerja terbaik.

Sebagai pembanding hasil pengelompokan dengan FCM, berikut diberikan pengelompokan karyawan yang didapat dari wawancara dengan manajer Oemah Djari Salatiga. Tabel 6 merupakan data pengelompokan karyawan dari manajer Oemah Djari Salatiga.

Tabel 6 Pengelompokan karyawan oleh manajer

\begin{aligned} \hline Kelompok & \multicolumn{1}{c}{ Karyawan } \\ \hline Kelompok 1 & ANDREAS \\ & ANGGRAENI \\ Kelompok 2 & EKO NUR IMAN \\ Kelompok 3 & AGUS \\ & ARDIAN \\ & DIKA \\ & IRUL \\ & NENSI \\ & NOVAN \\ & RAHMA \\ & RISKI \\ & RIVAEL \\ & SAINO \end{aligned}

\section{Simpulan}

Dari pembahasan yang telah diberikan pada bagian sebelumnya dapat disimpulkan bahwa FCM dapat digunakan untuk mendapatkan kelompok karyawan berdasarkan kinerjanya. Kinerja tersebut diukur berdasarkan tiga kriteria yaitu presensi, kedisiplinan, dan waktu penyelesaian pekerjaan. Dengan menetapkan jumlah kelompok karyawan sebesar tiga kelompok, FCM bekerja dengan baik dalam melakukan klasterisasi atau pengelompokan kinerja karyawan. Hal ini terbukti dengan diperolehnya kelompok karyawan yang sama dengan hasil pengelompokan yang dilakukan oleh manajer. Kelompok pertama merupakan kelompok karyawan dengan kinerja tidak baik, kelompok kedua merupakan kelompok dengan kinerja sedang, dan kelompok ketiga merupakan kelompok dengan kinerja yang baik. Selain itu, dengan nilai eksponen fuzzy yang berbeda, dihasilkan kelompok yang berbeda juga. Nilai eksponen fuzzy 1.5 dan 2 menghasilkan kelompok karyawan yang sama dengan pengelompokan yang dilakukan oleh manajer.

Penelitian ini dapat dikembangkan dengan menambahkan jumlah kriteria 
untuk penilaian kinerja karyawan. Dengan adanya hasil dari penelitian ini diharapkan dapat membantu manajer Oemah Djari Salatiga untuk mengevaluasi kinerja karyawan dan mengelompokkan karyawan berdasarkan kinerjanya, sehingga karyawan dapat diberikan reward dan punishment sesuai kinerjanya.

\section{Daftar Pustaka}

[1] A. Aidina, Ristyawan, Kusrini, Sunyoto, "Pemanfaatan Algoritma FCM Dalam Pengelompokan Kinerja Akademik Mahasiswa," Konf. Nas. Sist. Inform. 2015, pp. 431-436, 2015.

[2] F. Wulandari and R. Setiawan, "Clustering Karyawan Berdasarkan Kinerja Dengan Menggunakan Logika Fuzzy C-Mean," J. Penelit. Univ. Islam Negeri Syarif Kasim, Riau, pp. 1-7, 2010.

[3] F. Nasari and C. J. M. Sianturi, "Penerapan Algoritma K-Means Clustering Untuk Pengelompokkan Penyebaran Diare Di Kabupaten Langkat," CogITo Smart J., vol. 2, no. 2, p. 108, 2016, doi: 10.31154/cogito.v2i2.19.108-119.

[4] N. Agustina and P. Prihandoko, "Perbandingan Algoritma K-Means dengan Fuzzy C_Means Untuk Clustering Tingkat Kedisiplinan Kinerja Karyawan (Studi Kasus: Sekolah Tinggi Teknologi Bandung)," J. RESTI (Rekayasa Sist. dan Teknol. Informasi), vol. 2, no. 3, pp. 621-626, 2018, doi: 10.29207/resti.v2i3.492.

[5] A. K. Wijaya, "Implementasi Data Mining dengan Algoritma Fuzzy C Means Studi Kasus Penjualan di UD Subur Baru," Jur. Tek. Inform. FASILKOM UDINUS, pp. 1-8, 2014.

[6] A. A. Khoiruddin, "Menentukan nilai akhir kuliah dengan fuzzy c-means," in Seminar Nasional Sistem dan Informatika, 2007, pp. 232-238.

[7] J. Tamaela, E. Sediyono, and A. Setiawan, "Cluster Analysis Menggunakan Algoritma Fuzzy C-means dan K-means Untuk Klasterisasi dan Pemetaan Lahan Pertanian di Minahasa Tenggara," J. Buana Inform., vol. 8, no. 3, pp. 151-160, 2017, doi: 10.24002/jbi.v8i3.1317.

[8] R. A. M. S. D. Yuhandri, "PERBANDINGAN ALGORITMA K-MEANS CLUSTERING DENGAN FUZZY C- MEANS DALAM MENGUKUR TINGKAT KEPUASAN TERHADAP TELEVISI Jurnal Teknologi dan Sistem Informasi Univrab," vol. 3, no. 1, pp. 10-21, 2018. 